\title{
Edible Insects-the Future of a Healthy Diet?
}

\author{
Blanka Tobolkova*
}

Food Research Institute-National Agricultural and Food Centre, Slovakia

\section{Abstract}

The global population is increasing, it is estimated that in 2050 the human population will reach 9 billion. Generally, insect represents a valuable alternative source of proteins with nutritional benefits that cannot be neglected. Entomophagy, the eating of insects, can be promoted for different reasons:

ISSN: 2640-9208

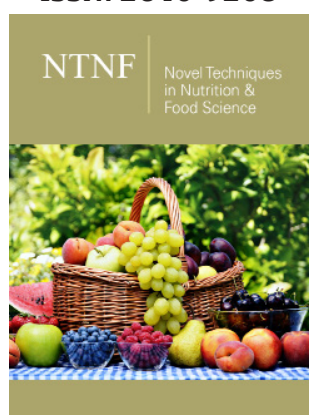

*1 Corresponding author: Blanka Tobolkova, Food Research InstituteNational Agricultural and Food Centre, Slovakia

Submission: 㯺 August 07, 2019

Published: 賎August 13, 2019

Volume 4 - Issue 2

How to cite this article: Blanka $\mathrm{T}$. Edible Insects-the Future of a Healthy Diet?. Nov Tech Nutri Food Sci. 4(2). NTNF.000584.2019.

DOI: 10.31031/NTNF.2019.04.000584

Copyright@ Blanka Tobolkova, This article is distributed under the terms of the Creative Commons Attribution 4.0 International License, which permits unrestricted use and redistribution provided that the original author and source are credited.
$>$ Insects are rich in nutrients (proteins, fat, fibre, vitamins and minerals)

$>\quad$ They are the most species-rich resources

$>$ Their farming can be a more sustainable practice than beef rearing

$>\quad$ They can be eaten a variety of ways

$>$ They taste great.

Keywords: Edible insects; Nutrition; Sensory analysis

\section{Introduction}

Insects have always been a part of human nutrition. However, in most countries, people still associate eating insects with primitive behavior [1]. It is estimated that more than 2100 species of insects are consumed in about 113 countries across Asia, Africa and Latin America [1-3]. The most frequently consumed insects are beetles (Coleoptera-659 species), caterpillars (Lepidoptera-362 species), bees, wasps and ants (Hymenoptera-321 species), followed by grasshoppers, locusts and crickets (Ortoptera-278 species) [1,4,5]. Edible insects are usually divided into 3 groups: food insects, drug/medicinal insects and drug dual-use insects. Besides serving as a food, insects offer a variety of other valuable products such as honey, silk and/or medicinal applications (e.g. maggot therapy) [1]. Common insect's products and services are listed in Table 1.

Table 1: List of common insects' products and services.

\begin{tabular}{|c|c|}
\hline Insects & Products \\
\hline Scale insects & Cochineal (carmine dye) [18] \\
\hline Bees & $\begin{array}{r}\text { Honey, propolis (natural medicine), royal jelly (beauty products), beeswax } \\
\text { (cosmetics and candles) [19] }\end{array}$ \\
\hline Human flea & Resilin protein (for artery repair) [20] \\
\hline Silkworms & Silk [21] \\
\hline Termites & Termite hills (architectural models) [22] \\
\hline Various insects & Pollination [23] \\
\hline
\end{tabular}

\section{Nutritional value}

It has been proven that insects have high nutritional value, although it is highly variable $[2,3,6]$. Significant variations were found in nutritional values of different species. Besides species variations, factors such as metamorphic stage of insect, their habit and diet, preparation and processing methods (e.g. boiling, drying, frying) may influence nutritional composition $[1,2,5]$. The main components of insect body are proteins, fats, fibre, nitrogenfree extract (NFE-carbohydrates other than fibre) and ash [7].

Proteins are the most significant components of insect body, comprising between 13\% and $77 \%$ of total dry matter, reflecting high variability of analyzed species [8]. Protein quality is determined by amino acid composition and the digestibility of the protein fraction [9]. 
Elorduy et al. [10] estimated digestibility of insect proteins to be between 77\% and 98\% [11]. Previous studies showed that insect's essential amino acid profile score ranges from $46 \%$ to $96 \%$ of total amino acids $[11,12]$. Generally, phenylalanine tyrosine, leucine and valine are dominant amino acids, while methionine, cysteine and tryptophan represent minor ones [7,11,13].

Fat represents the second largest portion of the nutrient composition of insects. The average fat contents range from $10 \%$ to $60 \%$ of dry matter, with larval stages having a higher fat content than adults $[5,7,11]$, although these values depend on insect diet and insect species. For instance, caterpillars and termites have the highest levels of fat (from 8.6 to $15.2 \mathrm{~g} / 100 \mathrm{~g}$ of insects), while grasshoppers and crickets are at the lower end (3.8 to $5.3 \mathrm{~g} / 100 \mathrm{~g}$ of insects) $[9,14]$. The lipid fraction of edible insects is rich in mono(MUFA) and polyunsaturated fatty acids (PUFA), with a high $\omega-3$ (omega 3): $\omega-6$ (omega 6) ratios [3]. The major MUFA of edible insects include palmitoleic (C16:1) and oleic acid (C18:1n9), while the two main components of PUFA are linoleic (C18:2n6) and $\alpha$-linolenic acid (C18:3n3). Palmitic acid (saturated fatty acid - SFA) content is also relatively high $[1,5,7]$.

Insects contain significant amount of fibre (crude fibre, acid detergent fibre and neutral detergent fibre). Chitin, an insoluble fibre derived from the exoskeleton, is the most common form of fibre in insects. Finke (2007) estimated that chitin content ranges from $2.7 \mathrm{mg}$ to $49.8 \mathrm{mg}$ per $\mathrm{kg}$ (fresh), and from $11.6 \mathrm{mg}$ to $137.2 \mathrm{mg}$ per kg (dry matter) [15]. In addition to proteins, fats and fibre, edible insects are a valuable source of minerals such as iron, copper, zinc, potassium, sodium, calcium, phosphorous, magnesium and manganese [1]. Edible insects can be rich also in vitamins such as thiamine (B1), riboflavin (B2), pantothenic acid (B5), vitamin E and retinol. Again, a large variation in mineral and vitamin contents is often seen between individual species due to environmental factors and contaminants, particularly metal, acquired during processing $[1,5,7,9]$.

\section{Sensory quality}

Although nutritional values are important, for steady intake a food has to be acceptable from a sensory point of view. In many counties' insects are consumed alive and/or processed by various methods such as steaming, roasting, frying, curing or smoking. On the other hand, various techniques of insect processing have been developed in order to increase consumer's interest in the Western countries. These techniques which include drying (e.g. sun-drying, freeze-drying, oven-drying, microwave-drying), ultrasoundassisted extraction, cold atmospheric pressure plasma or dry fractionation, are aimed primarily at using insects as ingredients in a non-recognizable form, such as powders or flours $[5,16,17]$. All the above-mentioned techniques may influence sensory properties of edible insects. Flavor and taste are very diverse (Table 2). Elorduy et al. [10] concluded that flavor and taste are mainly affected by pheromones occurring at the surface of the insect's body, by the environment, feed and/or processing methods. For instance, scalded insects are practically tasteless, because pheromones are washed off by rising [18-23]. Moreover, during cooking insects take the flavor of added ingredients $[5,10]$. Texture is influenced primarily by exoskeleton of insects. Most insect's adults are crunchy, while pupae, larvae and nymphs are not so crispy due to a minimal amount of chitin. Processing techniques also influence insect's texture. Fried, roasted or dried insects are crunchier/crispier that boiled ones [17]. Insects color is strongly affected by the processing methods and by the technological conditions applied. During cooking (boiling), the insects turn a reddish color [17]. On the other hand, insects that contain significant amount of oxidized fat or are inappropriately dried, may be black $[5,10]$. Smoked, properly dried or fried insects are golden or brown [17].

Table 2: Flavor and taste of selected edible insect species.

\begin{tabular}{|c|c|}
\hline Insect & Sensory Description \\
\hline Ants, termites & $\begin{array}{c}\text { Sweet; nutty; fatty; crunchy; notes of cereal } \\
\text { and wood }\end{array}$ \\
\hline Grasshopper & $\begin{array}{c}\text { Aroma of cereal, wood and nuttiness; flavour } \\
\text { of umami and vegetable; crusty; hard }\end{array}$ \\
\hline Cricket & $\begin{array}{c}\text { Popcorn; chicken; creamy; aroma of broth, } \\
\text { nuttiness and cereal; flavour of umami and } \\
\text { vegetable }\end{array}$ \\
\hline $\begin{array}{c}\text { Mealworm (Tenebrio } \\
\text { molitor) }\end{array}$ & $\begin{array}{c}\text { Nutty, umami, intense aroma of cereal, nut- } \\
\text { tiness and wood; flavour of nut, cereal and } \\
\text { umami; brittle texture }\end{array}$ \\
\hline
\end{tabular}

Source: Elhassan et al. [16] and Elorduy et al. [10]

\section{Conclusion}

Edible insects represent valuable source of nutrients and may be included among the common diet of consumers in the future. They could be used for direct consumption and/or as a nutritional ingredients and supplements for special diets. Insects can be regarded as safe, if properly managed and consumed. In addition, standardized conditions of their rearing and monitoring their composition are necessary to include potential suitable species of insects into the normal human diet.

\section{Acknowledgement}

This contribution is the result of the project APPV-17-0538 "Establishment of pilot facility and the development of mass rearing methods for edible insects' production".

\section{References}

1. Huis AV, Itterbeeck J, Klunder H, Mertens E, Halloran A, et al. (2013) Edible insects: Future prospects for food and feed security. FAO Forestry Paper.

2. Yin W, Liu J, Liu H, Lv B (2017) Nutritional value, food ingredients, chemical and species composition of edible insects in China. In: Mikkola $\mathrm{H}$ (Ed.), Future foods ( $1^{\text {st }}$ edn), BoD, Croatia.

3. Zielińska E, Baraniak B, Karaś M, Rybcyńska K, Jakubczyk A (2015) Selected species of edible insects as a source of nutrient composition. Food Res Int 77(3): 460-466.

4. Jongema Y (2017) List of edible insects of the world.

5. Kouřimská I, Adámková A (2016) Nutritional and sensory quality of edible insects. NFS Journal 4: 22-26.

6. Payne CLR, Scarborough P, Rayner M, Nonaka K (2015) Are edible insects more or less "healthy" than commonly consumed meats? A comparison using two nutrient profiling models development to combat over-and undernutrition. Eur J Clin Nutr 70(3): 285-291. 
7. Rumpold BA, Schlüter OK (2013) Nutritional composition and safety aspects of edible insects. Mol Nutr Food Res 57(5): 802-823.

8. Xiaoming C, Ying F, Hong Z, Zhiyong C (2010) Review of the nutritive value of edible insects. In: Durst PB, Johnson DV, Leslie RL, et al. (Eds.), Forest insects as food: Humans bite back. Proceedings of a workshop on Asia-pacific resources and their potential for development. FAO Regional Office for Asia and the Pacific, Bangkok, Thailand.

9. Dobermann D, Swift JA, Field LM (2017) Opportunities and hurdles of edible insects for food and feed. Nutr Bull 42(4): 293-308.

10. Elorduy JR (1998) Creepy crawly cuisine: The gourmet guide to edible insects. Park Street Press, South Paris, Maine, USA.

11. Elorduy JR, Pino JM, Prado EE, Perez MA, Otero JL, et al. (1997) Nutritional value of edible insects from the state of Oaxaca, Mexico. J Food Compos Anal 10(2): 142-157

12. Belluco S, Losasso C, Maggioletti M, Alonzi CC, Paoletti MG, et al. (2013) Edible insects in food safety and nutritional perspective: A critical review. Compr Rev Food Sci Food Safety 12(3): 296-313.

13. Foliart GR (1992) Insects as human food: Gene defoliart discussed some nutritional and economic aspects. Crop Prot 11(5): 395-399.

14. Sosa DAT, Yi LY, Valenberg HJF, Boekel MAJS, Lakemond CMM (2014) Insect lipid profile: Aqueous versus organic solvent-based extraction methods. Food Res Int 62: 1087-1094.

15. Finke MD (2007) Estimate of chitin in raw whole insects. Zoo Biol 26(2): 105-115.
16. Elhassan M, Wendin K, Olsson V, Langton M (2019) Quality aspects of insects as food-nutritional, sensory, and related concepts. Foods 8(3): $1-14$.

17. Lalanne GM, Álvarez AJH, Castro AS (2019) Edible insects processing: Traditional and innovative technologies. Compr Rev Food Sci Food safety 18(4): 1166-1191.

18. Nejad HE, Nejad AE (2013) Cochineal (Dactylopius coccus) as one of the most important insects in industrial dyeing. Int J Adv Biol Biomed Res 1(11): 1302-1308.

19. Huis AV (2003) Medical and stimulating properties ascribed to arthropods and their products in sub-Saharan Africa. In: Florac ÉM, Thomas JMC (Eds.), Insects in oral literature and traditions. Peters Publishers, Paris, France.

20. Elvin CM, Carr AG, Huson MG, Maxwell JM, Pearson RD, et al. (2005) Synthesis and properties of crosslinked recombinant pro-resilin. Nature 437: 999-1002.

21. Woo LY (1999) Silk reeling and testing manual. FAO Agricultural Services Bulletin 136.

22. Turner JS, Soar RC (2008) Beyond biomimicry: What termites can tell us about realizing the living building. First International Conference on Industrialized, Intelligent Construction (I3CON), Loughborough University, England, UK, pp. 1-18.

23. Getanjaly VL, Rai P, Sharma R, Kushwaha R (2015) Beneficial insects and their value to agriculture. Res J Agriculture and Forestry Sci 3(5): 25-30.

For possible submissions Click below: 